\title{
Interpersonal Metaphor of Mood in the Courtroom Interaction
}

\author{
Pera Handayani Harahap \\ English Applied Linguistics Study \\ Program \\ Universitas Negeri Medan \\ Medan, Indonesia \\ peraharahap@gmail.com
}

\author{
Anni Holila Pulungan \\ English Applied Linguistics Study \\ Program \\ Universitas Negeri Medan \\ Medan, Indonesia
}

\author{
Amrin Saragih \\ English Applied Linguistics Study \\ Program \\ Universitas Negeri Medan \\ Medan, Indonesia
}

\begin{abstract}
This study was investigated interpersonal metaphor of mood used in the Courtroom Interaction based on Systemic Functional Linguistics Approach. The objective of this study was to investigate the kinds of interpersonal metaphor of mood in the courtroom interaction. The research was conducted by using qualitative design. The data of this research were utterances of judge while doing the interaction with dependants. The data were taken from three sessions of courtroom interaction, they are indictment session, evidentiary session, and verdict session about narcotic case with a different dependants. The data were collected by using video recorder or tape recorder in the courtroom interaction that consists of utterances or clauses of judge, then transcribed them into written forms which contain interpersonal metaphor of mood, identifying the clause into kinds of interpersonal metaphor of mood based on Halliday theory and Saragih. The findings showed all kinds of interpersonal metaphor of mood, i.e declarative, interrogative, and imperative are used by judge in the courtroom interaction.
\end{abstract}

Keywords: Interpersonal Metaphor, Mood, Courtroom Interaction

\section{INTRODUCTION}

Language is the primary way of communication and a means of interaction each other. The interaction is done to express their feeling, share their ideas, and convey information. It is their tool to interact and communicate with others. Language as a formal system of sign governed by grammatical rules of combination to communicate meaning. This definition stresses that human languages can be described as closed structural systems consisting of rules that relates particular signs to particular meaning.

In addition, language has an important role in our lives. Not only in daily life but also in the media such in the courtroom. In courtroom, the function of language is limited as a device to express the extent of power. As Stubbs argues that language and the law is now a major area of Applied
Linguistics and a substantial amount of literature shows how linguistic analysis can be important for social issues. What Stubbs' argument implies the law is inseparable from society. It is there to accord importance to empirical research of social behavior, including language that carries the law. As Alisjahbana [1] states that language and law are interrelated, mutual influence, even considered as the incarnation of society and culture which is otherwise also influenced by language and law. Therefore, in the courtroom, they need language to convey their thought and ideas.

As explained above, one of the functions of the language in speech as proposed by Halliday [2] is interpersonal function where the language is used to enable us to participate with the communicative acts with other people. It means here in this function we use language to interact to other, to establish and maintain the social link with them. In interacting with other, we usually tell things for purpose such as influence people's attitude/behaviour and provide information

Interpersonal metaphor as one types of metaphor is often used by politicians or bureaucrats in order to make meaning ambiguous, but in this study the researcher used interpersonal metaphor in the courtroom interaction because the researcher wants to know the interpersonal metaphor in that place. As Saragih [3] states interpersonal metaphor occurs in the areas of politic, diplomacy and bureaucracy. Furthermore, Halliday adds it is very common if the bureaucrat or politician most used metaphorical than literal utterances or incongruent coding than congruent one. The use of incongruent or metaphorical utterances by politician deals with such factors in doing interaction with other people. One of grammatical metaphor which deals with the maintaining relationship among speakers while having interaction is interpersonal metaphor. Saragihstates that interpersonal metaphor covers the areas of speech function in mood, modality, epithet, mental process, euphemism and connotation. This research, however focuses only on metaphor of mood. 
In addition, interpersonal metaphor also occur in order to negotiate or in other cases avoiding negotiation. Thompson [4] explains that in interpersonal metaphors the non-negotiability associated with nominalization can clearly be a powerful weapon in cases where the speaker or writer wishes, for whatever reason, to avoid negotiation, with its possible outcome of rejection. While, Interpersonal metaphor is a strategy for expanding the potential for negotiation. It means that the possible used negotiation or avoid negotiation based on the genre of the interaction or text.

This study was referred to the use of interpersonal metaphor in the "Courtroom Interaction". Myers [5] states that courtroom is a miniature of the social world, which is human relations. It means that in the courtroom there is a process of mutual influence between law enforcement officers, namely judges, prosecutors, lawyers and even the public. Each of them has their own duties and functions in the room.

Courtroom is not going to be concerned in making this study, but what is going to be concerned in this study is the language use. Simply it can be mean that, this study is focused on interpersonal metaphor in the courtroom interaction. There are some reasons for choosing interpersonal metaphor used in the courtroom interaction as the object of the study. First, this courtroom is known for indirection in their behaviour, especially the speakers and the participant talk about unfamiliar things. Second, in the courtroom there are many cases such as divorce, theft, murder, drugs, and other criminal acts. Because the language used in the courtroom is different among the speakers and participants who are the suspects in the case.

Finally, this study was focused on interpersonal metaphor in the courtroom interaction which is rarely found or conducted due to the limitation of data sources. These facts serve to be a motivation to conduct the present study dealing with interpersonal metaphor used in the interaction in order to find out what kinds of interpersonal metaphor of mood in the courtroom interaction.

\section{LITERATURE REVIEW}

\section{A. Grammatical Metaphor}

Grammatical metaphor is a substitution of one grammatical class, or one grammatical structure, by another, for example, "his departure instead of his departed" Halliday \& Martin [6]. Halliday used the term grammatical metaphor to refer to the meaning transference from congruent to metaphorical in grammar. Congruent forms reflect the typical ways that people construe experience. In congruent forms, verbs represent actions or processes, nouns represent participants and adverbs or prepositional phrases represent circumstances and conjunctions express the relations between one process and another.

Halliday distinguishes two types of grammatical metaphors following his distinction of clause meaning, they are: (a) ideational metaphors, which are considered metaphors of transivity and (b) interpersonal metaphors, which are considered metaphors of mood and modality.

\section{B. Interpersonal Metaphor}

Halliday states that functional linguistics held that interpersonal metaphors are one of the devices to realize interpersonal meaning. Halliday also states that interpersonal component of grammar especially concerns the areas of modality and mood. Metaphor of mood as the realization of speech function. Typical examples of mood metaphors are "speech functional formula".

In interpersonal metaphor the speaker and addressee having a communication with different ways as common one and when having interaction. As Xue-feng [7] says that interpersonal metaphor involves non-congruent ways of informal spoken language which concerns with establishing and maintaining relations with other people enacting interaction correlated with a tendency to draw on the resources of interpersonal metaphor involved.

In addition, Bloor and Boor [8] say that language is used to enable us to participate in communication acts with other people, to take on roles and express and understand feelings, attitude and judgments. This function known as the interpersonal function.

\section{Kinds of Interpersonal Metaphor}

Saragih states that interpersonal metaphor covers the areas of speech function in mood, modality, epithet, mental process, euphemism and connotation.

\section{Metaphors of Mood}

Metaphor of mood is the exchanging system giving or demanding information or good and services, which determines the four basic speech function of statement, question, offer, and command. Furthermore, Saragih argues that they are termed as basic speech function because other specific or 'delicate' (the term used in SFL) speech function are potentially derived from the basic speech. Furthermore, Saragih explains the basic speech function of statement, question and command are congruently or commonly realized by the declarative, interrogative and imperative mood respectively. The speech function of offers does not have an unmarked or a common realization. In other words, the uncommon or un-congruent realization of basic speech function deals with metaphorical in metaphor of mood.

The speech roles in exchange are giving and demanding the commodity exchanged which are goods and services and information. "These are two variables, when taken together, define the four primary speech function of offer, command, statement and question". It means that each types of speech function are realized by mood type; declarative, interrogative and imperative which chosen by the speaker while having interaction with the addressee which deals with such topics. For clear, the realization of speech function (statement, question, command and offer) into mood (declarative, interrogative and imperative).

Thus Halliday claims that a statement is most congruently realized by means of the declarative type of mood and the most congruent expression of a question is a sentence of the interrogative type. Incongruent types of expression are 
especially important in the area of goods and services. The four kinds of speech function in language; offer, command, question, and statement are reflected by tone in the grammar.

\section{E. Metaphors of Modality}

Metaphor of modality is the incongruent form of modality. Halliday and Matthiessende fine modality as the speaker's judgments of probabilities, or the obligation involved in what she/ he is saying. Modality refers to intermediate ground between positive and negative polarity where the area of meaning between yes or no lies.

\section{F. Epithet}

The epithet indicates some of the subset, for example old, long, blue, fast. This may be an objective property of the thing itself or it may be an expression of the speaker's subjective attitude towards it, for example splendid, silly, and fantastic.

\section{G. Euphemism}

The other kind of interpersonal metaphor is euphemism. Euphemism is a word or phrase that is substitute for something which is more direct, more specific and is considered unpleasant, embarrassing of offensive or that has a stigma attached. For example; die changed to pass away.

\section{H. Connotation}

Connotation is very close to the meaning of the text or spoken language. As Gerald [11] states that connotation is a central part of meaning as 'the whole part of utterances may be to be expressing the speaker's attitude, evaluation and point of view'. The connotation deals with the speaker's attitude toward the language that he or she uses through his/her utterances that has a meaning.

\section{Mental Process}

The other type of interpersonal metaphor is mental process. Saragih states that it is inside the human participant reversible in participant. In saying something among the speaker and the addressee changed into metaphorical one.

\section{J. The Realization of Interpersonal Metaphor of Mood}

Generally, in having interaction among speakers deals with the roles of each speaker which deals based on the language function. It is discussed under the interpersonal function of SFL theory, where the speakers have role to demanding information or good and services while the addressee have a role to giving information or goods and services. Theoretically, the reasons are to making meaning ambiguity, politeness and avoiding negotiation.

\section{K. The Reasons of Using Interpersonal Metaphor of Mood}

Halliday states that languages always take place in a context. Context is the key in disgusting an idea or meaning of a communicating activity. The meaning of utterance is strongly influenced by its context. Context has a part to play, it uses different language in different situation with different people. In this case, the context has relation to linguistics meaning. It means that the meaning must related to context.

\section{The Social Context}

Halliday states that languages always take place in a context. It means that the use of language depends on the situation where the language used. In other words, it can be said that language is functioning in context of situation.

\section{a. The Context of Situation}

Context determines and is constructed by the choice of language. As Vlack said context related the surrounding situation in which can an utterance in uttered in speech or a sentence is written. Halliday \& Hassan state that there are three keys dimension of the situation are identified as having significant and predictable impacts on language use. They are followed by field (topic or focus of the activity), tenor (role relations of power and solidarity) and mode (amount of feedback and role of language).

\section{b. The Context of Culture}

The second element of social context is context of culture which is called genre. Saragih elaborates that genre itself covers stages, goal oriented social activity. A text is created in interaction by involving the two sides. They are followed by addresser and addressee. In other words, there is no text without interaction.

\section{c. The Context of Ideology}

Ideology is defined as a social construct that says what one should or should not do as a member of the community. In this sense ideology covers value, view, position or perspective. Ideology is determined by a number of factors, namely social class, sex, race or ethnic group and generation.

\section{Courtroom Interaction}

The Cambridge international dictionary of English defines the verb "to interact" as "to communicate with or react to (each other)". The new oxford dictionary of English defines the noun "interaction" as a "reciprocal action or influence". Therefore, interaction is more than action followed by reaction. It includes the acting reciprocally, acting upon each other. Tuan [9] describes the word through its Latin roots: 'agree' meaning 'to do' and 'inter' meaning 'among'. It shows us the active and social part of a human being that affects other people through interaction.

Courtroom interaction is institutionalized talk. There has been organized and setting the rule on how the interaction is held. The courtroom is a stage for the display of linguistic power at work, with various actors performing largely linguistic acts in the discursive choices in representing and reconstructing stories or events in real life. Therefore, court as institutionalized organization displays linguistic power each actor in court has the power to restrict the audience to talk; even in question-answer session.

Courts are agencies officially that carry out the justice system in the form of examining, hearing, and deciding cases. 
Myers states that courtroom is a miniature of the social world, which is human relations. It means that in the courtroom there is a process of mutual influence between law enforcement officers, namely judges, prosecutors, lawyers and even the public.

\section{METHODOLOGY}

This study was conducted by using descriptive qualitative design, which the natural setting as the direct source of data. The data are collected in the form of words or pictures rather than numbers. Qualitative means to find out how a theory works in different phenomena. So, in this study to find out how the theory of interpersonal metaphor is used in the courtroom interaction. This research is designed with single case system where it is conducted only in the courtroom interaction.

The data of this study were clauses produced by judge which contain interpersonal metaphor while doing the interaction in the courtroom at Medan. The source of the data of this study were judge and dependents while doing the interaction in the courtroom. The researcher took one case of criminal act is narcotic case which obtained the data as much as possible to answer the research problems. The data was taken from three sessions of courtroom interaction, they are indictment session, evidentiary session, and verdict session.

The utterances was transcribed into written text and clauses will be found. The data was collected from courtroom interaction, it was held on August at 2019 will be analysed. It means that the researcher came to the courtroom about four times in a month for taking a data.

Bodgan \& Biklen[10] said that qualitative research is the research has the natural setting as the direct source of data and the researcher is the key of instrument. Because the researcher as the point of people who want to find out the research problems itself. The researcher observed and took passive participant in this research by finding the accurate data. In this research, the researcher will be used video recorder and tape recorder in collecting the data in order to be more systematic, effective, and easier.

In technique of collecting the data, the researcher in this research applied tape recorder or video recorder and interview to collect the data in order to obtain clear the interaction by judge and dependant in the courtroom. Then, the interview applied to know the reasons why judges use interpersonal metaphor of mood in the way they are. This interview is done after the recording among judge and dependant. To obtain the data from this interview, the researcher also uses the tape recorder to obtain the utterances.

The data was analysed by using interactive models by Huberman \& Saldana [11] the steps are data condensation, data display, and data drawing/verification.

\section{Data Condensation}

The condensation refers to the processes of selecting, focusing, simplifying, abstracting and transforming. a. Selecting : In this process, the utterances of judge and dependant are selected which contain interpersonal metaphor in the courtroom interaction.

b. Focusing : In this process, the researcher will only focus on utterances which contain interpersonal metaphor of mood in the courtroom interaction.

c. Simplifying : In this process, simplifying by categorizing the written text into kinds of interpersonal metaphor of mood in order to make them easier to be classified.

d. Abstracting : In this process of making written summary the data related to kinds of interpersonal metaphor of mood used by judge and dependant in the courtroom interaction.

e. Transforming: In this step, the researcher displays the data into written summary.

In this step, after selecting the utterances of courtroom interaction which contains interpersonal metaphor of mood, the researcher makes the texts into table. In conclusion drawing, the researcher concludes what kinds of interpersonal metaphor of mood used in the courtroom interaction. The trustworthiness of the study is based on the model by Lincoln \& Guba [12] in which credibility, transferability, dependability, and conformability are established in collecting and analyzing data.

1. Credibility

2. Transferability

3. Dependability

4. Confirmability

\section{IV.FINDING AND DISCUSSION}

After analyzing the data, the data are classified into kinds of interpersonal metaphor of mood used by judge while doing the interaction with dependent in the courtroom. In describing the data of interpersonal metaphor of mood realization, the study described interpersonal metaphor of mood that applied in judge' utterances by also presenting congruent and incongruent form. According to Halliday the interpersonal metaphor of mood exist when the speech functions are incongruently realized in mood kinds for instance statement metaphorically realized interrogative and imperative, question metaphorically realized in declarative and imperative and command metaphorically realized in declarative and interrogative. The kinds of interpersonal metaphor of mood found in the courtroom interaction by judge consisted of four categories, namely declarative mood to metaphorically realize command, declarative mood to metaphorically realize question, interrogative mood to metaphorically realize statement, imperative mood to metaphorically realize statement. The kinds of interpersonal metaphor of mood found in the courtroom interaction by judge consisted of four categories, namely declarative mood in command, interrogative mood in statement, declarative mood in question and imperative mood in statement. Therefore, the three kinds 
of interpersonal metaphor of mood are used in the courtroom interaction by judge.

TABLE 1. INTERPERSONAL METAPHOR OF MOOD USED BY JUDGE IN THE COURTROOM INTERACTION

\begin{tabular}{|c|c|c|c|}
\hline Mood & $\begin{array}{c}\text { Speech } \\
\text { Function }\end{array}$ & Total & \% \\
\hline Interrogative & Statement & 39 & 60 \\
\hline Declarative & Question & 1 & 1.5 \\
\hline Declarative & Command & 15 & 23.07 \\
\hline Imperative & Statement & 10 & 15.4 \\
\hline Total & & $\mathbf{6 5}$ & $\mathbf{1 0 0}$ \\
\hline
\end{tabular}

Based on the table 1 above, the judge dominantly used interrogative mood to metaphorically realize in statement in their utterances with the percentage of $(60 \%)$, declarative mood to metaphorically realize in question with the percentage $(1.5 \%)$, and declarative mood to metaphorically realize in command $(23.07 \%)$, imperative mood to metaphorically realize in statement $(15.4 \%)$.

The dominant used interpersonal metaphor of mood showed that mostly judge wanted to shorten the social and physiological distance between dependents which was realized by using statement in interrogative mood, include the whole participants in intended in the courtroom which was realized by using command in declarative mood to persuade the defendant implicitly into accepting judge arguments by raising a question demanding response from dependent which realized by using question in declarative mood, and make the judge ' view sound more authoritative which was realized by using statement in imperative mood.

\section{ACKNOWLEDGMENT}

The writer would like to express respectfulness to Dr.Anni Holila Pulungan, M.Hum and Prof. Amrin Saragih, M.A, Ph.D as her thesis advisor for guiding her to accomplish her thesis and for giving useful knowledge and suggestion.

\section{REFERENCES}

[1] Alisjahbana, S.T. 1974. Tata bahasa baru Bahasa Indonesia Jilid II. Jakarta: Dian Rakyat.

[2] Saragih, Amrin. 2014. Variation and Functional Varieties of Language. Medan: English Applied Linguistic Study Program Postgraduate Studies State University of Medan.

[3] Thompson, G. 1996. Introducing Functional Grammar. Beijing: Foreign Language Teaching and Research Press.

[4] Myers, D.G. 1990. Social Psychology. New York: Mc Graw Hills, Inc

[5] Halliday, M. A. K. \& Martin, J. R. 1993. Writing Science: Literacy and Discursive Power. London: Falmer Press.

[6] Xue-Feng, W. 2010. Grammatical Metaphor and Its Difficulties in Application. Vol.8, No.12 US-China Foreign Language. Taiyuan Normal University, Taiyuan 030012, China

[7] Bloor, T \& M, Bloor, 1995. The Functional Analysis of Language. New York: Oxford.

[8] Gerald, E. 2005 Euphemism. Retrieved from http://spanish.about.com/old/spanishvocabulary/g/euphemism_g

[9] Tuan, T.L. and Nhu, K.T.N. 2010. Theoritical Review on Oral Interaction in EFL Clasrooms. Studies in Literature and Language. Retrieved from www.cscanada.net.Vol.1, No.4, pp.29-48.

[10] Bogdan, C, R., \&Biklen, S. K. 1992. Qualitative Research for Education: An Introduction to Theory and Methods ( $2^{\text {nd }}$. Ed). Sydney: Allyn\& Bacon.

[11] Miles, M. B., Huberman, A. M. \& Saldana, J. 2014. Qualitative Data Analysis: A Methods Sourcebook (3rd ed). Arizona State University, CA: Sage.

[12] Lincoln, Y. S., \&Guba, E, G. 1985. Naturalistic Inquiry. New Bury Park, CA: Sage Publications 